Maria Trojanek "The UK and Poland's mortgage market: a comparative analysis", Journal of International Studies, Vol. 2, No 1, 2009, pp. 26-39.

\title{
The UK and Poland's Mortgage Markets: a Comparative Analysis
}

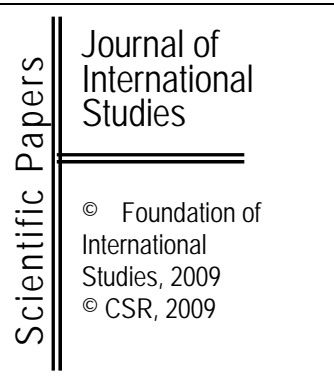

Prof. dr. hab. Maria Trojanek

Katedra Inwestycji i Nieruchomości

Uniwersytet Ekonomiczny w Poznaniu

r.trojanek@u,ue.poznan.pl

\begin{abstract}
Political transformations that took place up to the middle 1990s caused dynamic growth of the Polish mortgage market. From that time dynamics of mortgage debts is much higher. Mortgage loans are the best developed area of both commercial and mortgage banks.
\end{abstract}

Keywords: mortgage market, cooperative financial societies, Great Britain, Poland

JEL classification: G21, P2, P51

\section{Introduction}

At the end of the 1980s, the beginning of the 1990s cooperative financial companies were the leaders of mortgage market in Great Britain. The beginning of their activities dated back to $18^{\text {th }}$ century. Until 1874 they acted in form of associations and then after the bill of cooperative financial companies had been passed, they received legal entity. Their percentage share of the market amounted to $75 \%{ }^{1}$. The situation on the market changed completely within some years. In 2000 the market share of banks within the mortgages came to $70 \%$ and cooperative financial companies lost their leading position. Data concerning percentage share of subjects in the mortgage market have been assessed as average ones and they do not present the significant position of Abbey which owed around 10\% of the market in 2007.

Despite the fact that the Polish mortgage market is far less developed that the British one, its beginnings date back to $17^{\text {th }}$ century. The Silesian Land Mortgage Credit Society was established at that time. It supported the rebuilding of arable farms after the ravages of three Silesian wars. The objective of landowners united within the Society was to raise cheep loans for agriculture.

At the beginning of $19^{\text {th }}$ century there was established the Land Mortgage Credit Society that granted long-term loans. Moreover, in the interwar period, there were established fourteen urban mortgage credit societies that initiated the first mortgage banks. Unfortunately mortgage activity was stopped at the beginning of World War II. This activity has been resumed at the beginning of the $1990 \mathrm{~s}^{2}$. The Polish mortgage market is dominated by banks.

Cooperative financial societies in Poland, so-called SKOKs, received licence to grant mortgage loans quite recently i.e. at the end of 2006. SKOKs situation is much better than the

\footnotetext{
1 J.Nellis, The changing structure and role of building societies In the UK financial service sector, in: Management in the Service Sector, Kogan Page Cranfield Management Research Series, 1993, p.124-128

${ }^{2}$ BRE Bank Hipoteczny, Historia kredytów hipotecznych i listu zastawnego, www.rhb.com.pl dated 20.11.2007.
} 
situation of banks that must form and transfer reserves to the National Bank of Poland. SKOKs also need not to transfer any financial means to banking guarantee fund, hence theoretically - they have unlimited possibilities to grant loans on better conditions. But reality shows that clients trust banks more. ${ }^{3}$.

Political transformations that took place up to the middle 1990s caused dynamic growth of the Polish mortgage market. From that time dynamics of mortgage debts is much higher ${ }^{4}$. Mortgage loans are the best developed area of both commercial and mortgage banks ${ }^{5}$.

\section{Legal systems of Polish and British mortgage markets}

The British mortgage market is supervised by the Financial Services Authority. It acts upon the Financial Services and Markets Act from 2000. The FSA supervises, among others, consumers' protection against unfair actions of various financial institutions and proper markets activities. The FSA published the Mortgage Conduct of Business Sourcebook that is obliged for all institutions granting loans. This organisation is independent and the British Government bears responsibility for its activity ${ }^{6}$.

The Polish mortgage market is supervised by the National Bank of Poland and partly by the Council of the Monetary Policy (RPP) that regulates interest rates' level. All Polish banks are supervised by the Polish Banking Supervision Authority. Its main task is to audit banks within the observance of law, statute and financial regulations. Main sources of legal articles in Poland are the Banking Act and the Letter of Pledge and Mortgage Banks Act dated August 29, 1997. A number of "Recommendations" enacted by the Polish Banking Supervision Authority regulate functioning of mortgage market.

In Great Britain there exist some acts that must be obeyed by financial institutions. There are: the Building Sodeties Act from $1986^{7}$, the Financial Services Act of $1987^{8}$ and the Banking Act of $1987^{9}$. Enacting of them was a great step to liberalisation of mortgage market after "straightjacket" had been abolished.

It is hard to describe the Polish market as a liberal one. Although many commercial banks extended their offer by mortgage loans within the last years, we must have in mind very restrictive nature of regulations ${ }^{10}$. That was probably no intention of politicians who wanted to recover property market and to make mortgage loans easier available ${ }^{11}$. Meanwhile existing regulations make hard mortgage banks to have a competitive advantage over universal banks. In the Letter of Pledge and Mortgage Banks Act there were many unclear aspects regarding activity. They were partly supplemented by "Recommendations" enacted by the Polish Banking Supervision Authority.

Starting from 1998 supervision over the British market has been taken by the Financial Services Authority. When the Banking Act came into force all details concerning transfer of entitlements started to be clear. The Bank of England, however, follows a level of interest rates and is ready to appeal in case of danger of violent inflation. Besides these two organisations very important role plays the HM Treasury that acts as the ministry of finance

\footnotetext{
${ }^{3}$ SKOKi wskakują na rynek kredytów hipotecznych, www.money.pl

${ }^{4}$ A.Szopa, Bariery rozwoju rynku kredytów hipotecznych udzielanych na cele mieszkaniowe w Polsce, 2005 p.1

${ }^{5}$ Sytuacja..., www.inwestycje/nieruchomosci

6 www.fsa.gov.uk

7 The Building Sodeties Act, 1986

8 The Financial Services Act, 1987

9 The Banking Act, 1987

${ }^{10}$ P.Cyburt, Prawne i ekonomiczne aspekty działalności banków hipotecznych, www.nbportal.pl, 13.02.2007,p.1

11 As above, p.6
} 
and economy. Its task is to form and enforce the Governments' orders ${ }^{12}$. In the course of liberalisation of law in the United Kingdom new possibilities within the activity of cooperative financial companies and banks started to exist. Banks could not grant mortgage loans because of restrictive law and "straightjacket" existing from the beginning of 1980s.

Polish institutions teach themselves from the western ones how to manage with risk, how to develop mortgage products and how to build relationship with clients. That is why Polish novelties are often known on complicated and more competitive British mortgage market.

\section{Structure and action of mortgage markets in Poland and Great Britain}

Structure and action of Polish and British mortgage markets is very hard to compare because of differences of development level of both markets and many other aspects. British mortgage market is very well-developed and number of market players fight to dominate. It is characterized by long-standing tradition connected mainly with activities of cooperative financial institutions. Polish market which beginnings date back to $17^{\text {th }}$ century, i.e. hundred years earlier than the British one, was not developed so quickly. Sources of this situation were various circumstances including an outbreak of World War II and some solutions regarding economic system. Rules of functioning of banking system changed together with changes of economy.

\section{Graph 1. Share of mortgage loans in the GDP in Poland and Great Britain in 2006 and 2007}

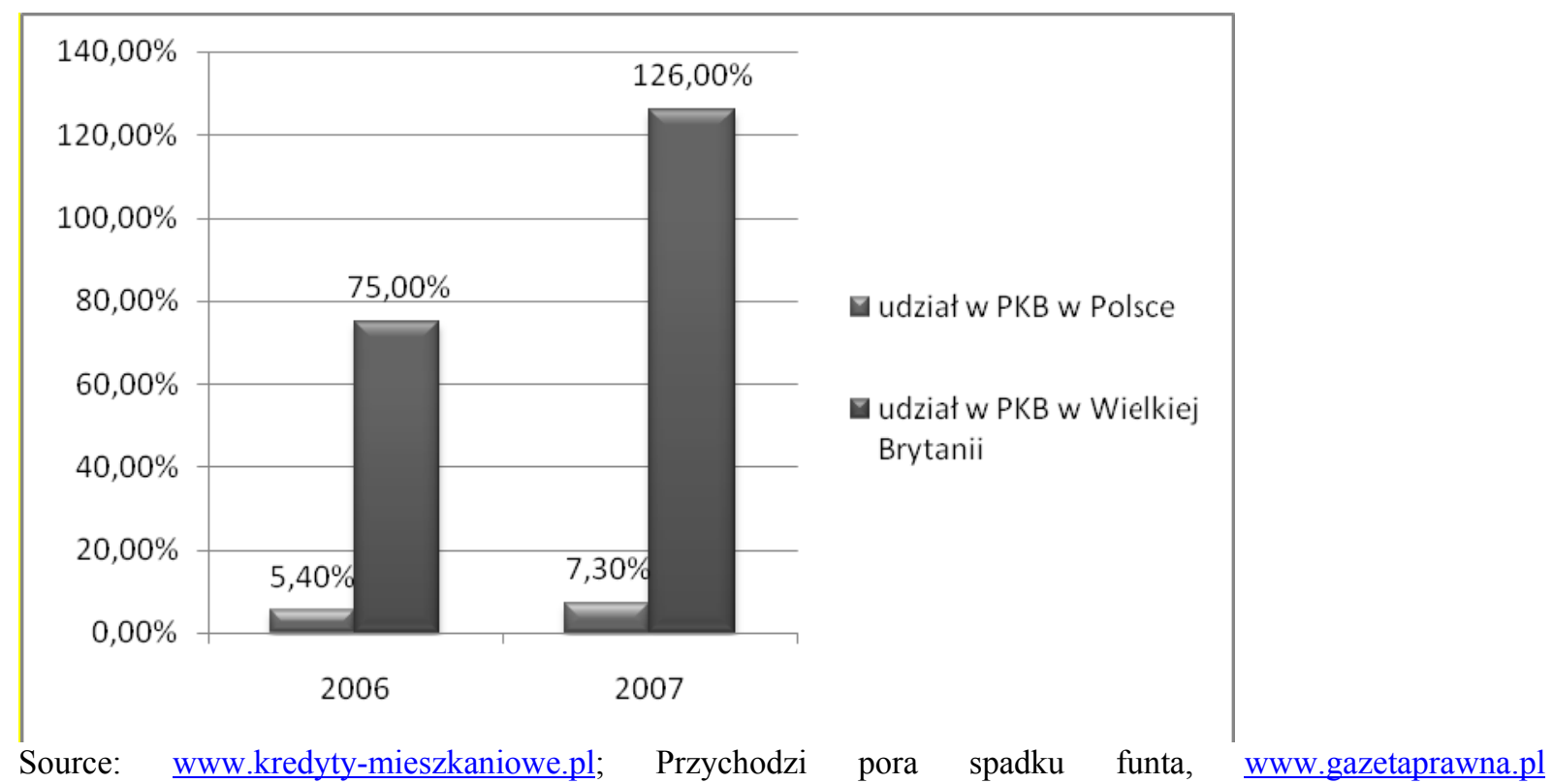

According to report of Bank Millenium mortgage loans in Poland in 2006 made 5.4\% of GDP, year later $7.3 \%$ only. In Great Britain at the same time this indicator amounted to $75 \%$ and $126 \%$ of GDP respectively (graph 1$)^{13}$.

There is great diversity between a share of mortgage loans in GDP in Poland and Great Britain. Forecasts for Poland show that at this rate of development of the Polish mortgage market our country can start to compare with western countries in 7-8 years time. It

\footnotetext{
12 www.un-treasury.gov.uk

13 www.kredyty-mieszkaniowe.pl; Przychodzi pora spadku funta, www.gazetaprawna.pl.
} 
is estimated that a share of mortgage loans in GDP could amount to somewhat higher than $35 \%$.

Dynamics of changes in discussed period is worth to note. Within 2007 a share of mortgage loans in GDP in Poland increased by 35\% and this growth in Great Britain was quite doubled at the same time - it reached $68 \%{ }^{14}$.

Activities on the British mortgage market are run by cooperative financial companies, banks, insurance companies and intermediaries. Competition is very fierce not only among banks and cooperative financial companies, for example, but also among banks themselves or cooperatives themselves. Clients attach greater significance to intermediaries number of whose increases very quickly $\left(12,000^{15}\right.$ new intermediaries arrived in 2003); there were 6846 intermediaries in $2007^{16}$ that shows more concentration on the market. The best developed channel of distribution of mortgage loans in Great Britain build financial and credit intermediaries. More than $60 \%$ of all loan agreements are concluded by intermediaries. Their role is that they are more clients' advisers than lenders. They grant full advisory services within proper mortgage product, they analyse individual situation of a client, his needs and preferences $^{17}$.

In Poland cooperative financial companies known as SKOKs received the right to grant mortgage loans in 2006 only. At present their loan offer is too expensive. For example interest rate of mortgage loan in SKOK Stefczyka amounted to 7.7\% (June, 2007) while it amounted to ca. $6 \%{ }^{18}$ in banks. Besides cooperative financial companies, credit intermediaries and independent credit advisers act on the market. Borrower may receive through them much information and also take out a loan both in mortgage or universal bank. Intermediaries are often pressed more for commission they receive from bank for granting a loan than for giving full information or matching the best solution for a client. Independent advisers have offers of many banks, they can professionally calculate lending capacity, match an individual client the most optimal loan, i.e. amount of instalments, time of repayment, additional insurances.

Concentration of the Polish mortgage loan market increases moderately through takeovers among banks as it took place in 2004 between BRE Bank and Rheinhyp - BRE Mortgage Bank ${ }^{19}$. Additionally, data of the Central Statistical Office weigh in favour of high concentration: in $200798.5 \%$ of all loan agreements were signed by banks ${ }^{20}$. Banks have much more confidence within borrowers than intermediaries.

In Great Britain insurance companies acting as financial or credit intermediaries can grant mortgage loans while in Poland they can only help to meet bank's requirements by taking out insurance policies (life insurance or involuntary unemployment cover) for borrowers. Technological progress concerning both analysed countries enables using of many information sources without the need of leaving home. Sustained struggle for clients resulted in appearance of many financial web portals and forums that are the most independent sources of information. Both in Poland and in Great Britain you can calculate instalments using virtual calculators and you can acquaint with bank handbook and to assess an offer yourself. ${ }^{21}$

14 www.kredyty-mieszkaniowe.pl; Przychodzi pora spadku funta, www.gazetaprawna.pl

15 D.Miles, The UK Mortgage Market: Taking a Longer-Term View. Final Report and Recommendations, The Miles Review, 2004, p.36

${ }^{16}$ As above

${ }^{17}$ Response from the Association of Mortgage Intermediaries (AMI) to the Mortgage Funding Expert Group and Consumer Industry Dialogue Group Final Reports, 2007

${ }^{18}$ M.Samcik, www.skok.pl.

${ }^{19}$ Decision No. DAR-4/2004 dtd 07.04.2004, www.uokik.gov.pl/download

${ }^{20}$ Działalność przedsiębiorstw pośrednictwa kredytowego 2007 roku, Informacje bieżące GUS dtd 28.05.2008, www.gus.gov.pl

${ }^{21}$ B.Półtorak, Kredyt hipoteczny Szansa na własne mieszkanie czy pułapka, www.bankier.pl dtd 14.05.2008 
Graph 2. Structure of mortgage loans granted in Great Britain in 1993-2007 (\%)

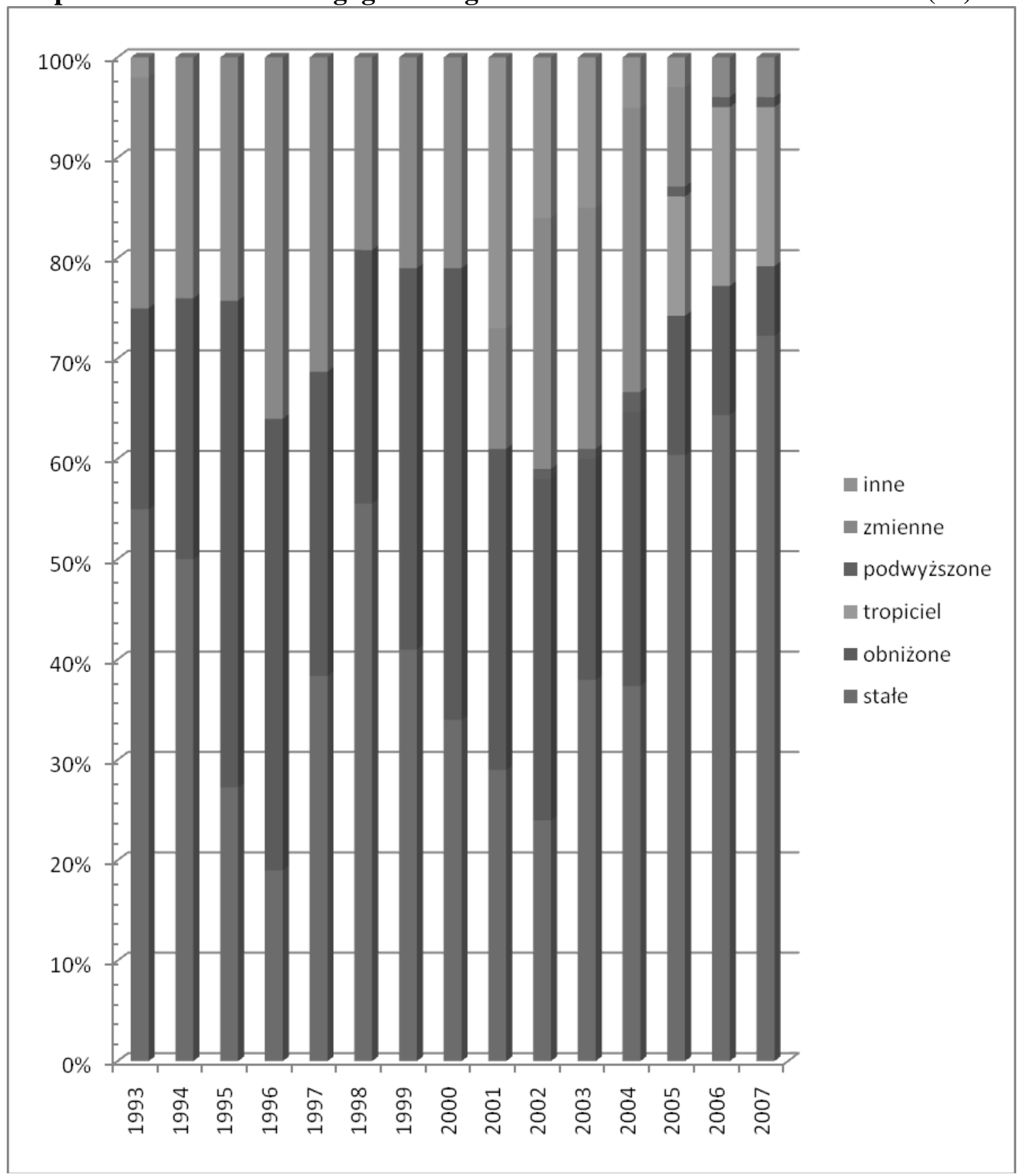

Source: own researches basing on the data of the Bank of England

Very characteristic for the Polish mortgage market is that mortgage banks are less flexible in comparison to universal ones because of regulations of the Letter of Pledge and Mortgage Banks Act.

Mortgage banks do not have any right to grant mortgage loan for $100 \%$ of property value in contrast with universal banks. Poor sales network does not allow them to develop. Good forecast for their future is, however, a stricter banking system supervising granting credits by universal banks. ${ }^{22}$

Structure of percentage of mortgage loans in Great Britain was very variable in 1993-

\footnotetext{
${ }^{22}$ Rynek kredytów hipotecznych: Banki hipoteczne poniosły fiasko, www.bankier.pl
} 
2007 what shows graph 2. The biggest differences are perceptible in 1996 when debt ratio of fixed loan rate did not exceed $20 \%$ and in 2007 when not more than $20 \%$ of borrowers chose loans with variable loan rates. Up to 2004 on the UK market mortgage debt with variable loan rate amounted to more than $60 \%$ of total debt. This tendency turned to loans with fixed loan rate. From 2002 till 2007 their share significantly increased. In 2007 debt of mortgage loans with fixed loan rate exceeded $70 \%$ of all mortgage loans granted.

Poland cannot be proud of as wide range of mortgage loans as Great Britain is. Mortgage loans in Poland are divided according to percentage into fixed and variable loan rate's credits. These first are new on the market and they are not popular at present because of their higher price. The most important is mentality of Polish borrowers that obliges them to save even if long-term credit with variable loan rate could appear more expensive that fixed loan rate credit. Households agree to risk taking out credits with variable loan rate and it resulted from another than Polish approach to own money and from relatively higher salaries in the UK. Decision regarding such a loan is taken of course basing on factors such as instalment and interests rates.

When the US mortgage market faced increasing crisis, on the British market developed a tendency to take loans with fixed loan rates, as presented in graph 2. Fixed loan rate secure a borrower against sudden fluctuations of short-term percentage rates and against increasing margins of lenders. Lenders who locate some part of their capital in the USA can now in short time increase a margin to compensate overseas losses with higher revenues from mortgage loans' repayments. Borrowers, however, analyse the situation and they more often choose credits with fixed loan rate that is individually set $^{23}$. Deutsche Bank enables receiving a loan in which fixed percentage is binding for first five years maximum. When a borrower is granted a credit in zlotys he pays the least choosing fixed percentage for five years $(6.92 \%)$. If he decides for a loan in Swiss francs, he ought to choose fixed percentage valid for first twelve months $(4.11 \%)^{24}$.

Poland is characteristic of young, bad developed market on which possibility of choosing of mortgage loans' percentage is still little and restricts itself to offering credits with fixed or variable loan rates. There is also a possibility of repayment form's choice as, for example suspension of repayment for definite period or decrease and increase of instalments due to needs. Payment holiday offers for instance GE Money Bank that makes easier a break in repayment for three months period from a baby's birth or adoption, especially for young people who plan to grow a family. ${ }^{25}$ From the very beginning of its loan activity there were granted mortgage loans with fixed loan rate WIBOR only enlarged with margin. As mentioned before only three banks in Poland offer mortgage loans with fixed loan rate: Danish Nykredit Mortgage Bank, Deutsche Bank PBC and BPH Mortgage Bank. ${ }^{26}$ Nykredit offers the best solution - loan in Euro only with percentage fixed in advance for the whole period of loan agreement (even 30 years). BPH Mortgage Bank offers a loan in zlotys and its fixed percentage is binding for the first ten years maximum. It means that a person who decides to take a loan for 30 years has to fix its percentage three times together with bank.

Every five years fixed loan rate is calculated in Deutsche Bank. Benefits for a client derive from possibility of choosing loan's currency from euro, zloty, US Dollar and Swiss franc. In case of two last banks taking a loan with fixed loan rate does not guarantee any invariability of instalments within the whole twenty- or thirty-year period. Even in Nykredit clients are not sure a level of monthly instalment because of currency risk for currencies

\footnotetext{
23 www.bphbh.pl

24 www.deutsche-bank-pbc.pl

${ }^{25}$ Nowości w ofercie kredytów hipotecznych GE Money Bank, www.bankier.pl, 2007

${ }^{26}$ M.Wielgo, Czy opłaca się wziąć kredyt o stałym oprocentowaniu?, gospodarka.gazeta.pl
} 
denominated in euro. ${ }^{27}$

In comparison to British banks and other financing institutions that sell very complicated loans often connected with a capital market, Polish mortgage loan offer seems to be very poor although Polish market draws on the experience of western countries. ${ }^{28}$ At present you need not to take a loan in a bank in which you have your personal account. Thanks to development of competition clients are able to run up a debt in any bank.

Financing of property taking into account LTV (Loan to Value) index amounting to $100 \%$ is practiced both in Poland and Great Britain. Very low own contribution has to be insured as it amounts to $20 \%$ of property value in Poland and $5 \%$ only in Great Britain. ${ }^{29}$ Tables 1 and 2 allow comparing a level of LTV index in Poland and Great Britain.

Table 1. Level of LTV index on mortgage markets in Great Britain (2007)

\begin{tabular}{|l|c|}
\hline Lender & LTV \\
\hline HBOS & $60-90 \%$ \\
\hline Abbey & $75-85 \%$ \\
\hline Lloyds TSB & $60-90 \%$ \\
\hline Nationwide & $75-90 \%$ \\
\hline Northern Rock & $70-80 \%$ \\
\hline The RBS & $75-95 \%$ \\
\hline Barclays & $60-90 \%$ \\
\hline
\end{tabular}

Source: Own researches based on data from www.mortgages.co.uk

LTV level less than $100 \%$ means that a lender/bank demands own contribution and does not grant any loan for a whole amount necessary to buy or to construct a house or an apartment. Lender sets, apart from percentage, a sum of loan that translates into LTV level. Lender takes into consideration many factors such as lending capacity and a necessity of insurance that increases LTV index. The highest LTV levels are in Poland. It results often from requirement to insure a loan in order to protect a lender from losses of instalments not paid off. Lower LTV levels are observed in Great Britain where lower loans are granted in fear of results of crisis on the US mortgage market.

Moreover, a period of credit in the UK and in Poland is similar and lasts up to 50 years (in Poland) and up to 60 years (in the UK). Some similarities appear when speaking about types of mortgage loans granted. In Great Britain, for instance, you can be granted credit with discounted rate mortgage for definite period of time.

\footnotetext{
27 As above

${ }^{28}$ Rynek kredytów hipotecznych 2005, egospodarka.pl

${ }^{29}$ Praca zbiorowa pod red. K.Jajuga i Z.Krysiak, Ryzyko kredytowe wierzytelności hipotecznych: modelowanie $\mathrm{i}$ zarządzanie, ZBP, Warszawa 2004, p. 432-437
} 
Table 2. Level of LTV index on mortgage markets in Poland (2007)

\begin{tabular}{|l|c|}
\hline Bank & LTV \\
\hline GE Money Bank & $95-100 \%$ \\
\hline Bank Millenium & $80-100 \%$ \\
\hline mBank & $100 \%$ \\
\hline DomBank & $130 \%$ \\
\hline Santander C.B. & $100 \%$ \\
\hline Deutsche Bank pbc & $110 \%$ \\
\hline MultiBank & $80-100 \%$ \\
\hline PKO BP & $80-100 \%$ \\
\hline Fortis Bank & $100 \%$ \\
\hline Bank BPH & $60-100 \%$ \\
\hline BZ WBK & $80-100 \%$ \\
\hline
\end{tabular}

Source: Own researches based on data from banki.com.pl

In Poland such type of a credit does not exist, however, in the way of negotiations bank can discount mortgage rate for some first years of repayment and after this time client has to pay off instalments due to standard variable loan rate.

\section{Development of mortgage loans prices in Great Britain and in Poland}

Both in Great Britain and in Poland mortgage loan markets are still developing, especially in Poland where debt level is increasing extremely quickly.

Debt level of mortgage loans increases in Poland violently year by year (graph 3). Especially in 2005-2007 number of mortgage loans increased seriously. Debt level in 2006 exceeded 77 billion zlotys. Within the next twelve months dynamic growth of 50\% meant that debt level came close to 117 billion zlotys.

High dynamics of debt level connected with mortgage loans is even not stopped by some complicated legal regulations and restrictions as, for example, "Recommendation S" regarding granting credits in foreign currencies that has to limit mortgage loans' availability for less wealthy people.

Graph 4 shows dynamics of mortgage loan debts in Poland in 2002-2007 (year $2002=$ 100). Within the researched period dynamics of mortgage loan debts were quite six time higher in 2007 than in 2002. You can notice distinctive change in 2005 when debt level was doubled in comparison to 2005 - from 19.7 to 45.8 billion zlotys. Next year debt level was four times higher than in a base year and later on - six times higher.

Currency of loan is very important factor. In Great Britain households and developers take mortgage loan in local currency, i.e. GBP. Poland, on account of lower competitiveness of loans in zloty, offers also mortgage loans in foreign currencies: Swiss francs, US Dollars and euro. 


\section{Graph 3. Debt level of mortgage loans in Poland in 2002-2007 (billion zlotys)}

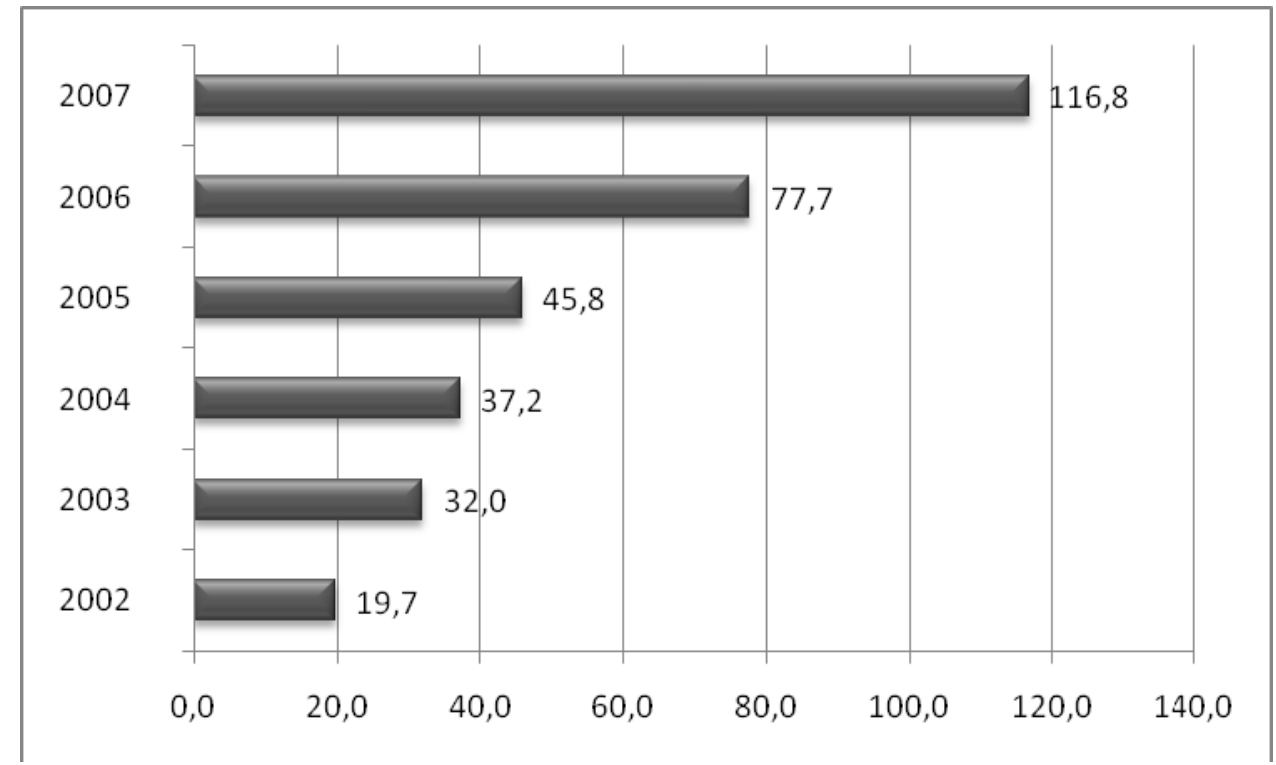

Source: Own researches based on: NBP, A. Szopa, Bariery rozwoju rynku kredytów hipotecznych udzielanych na cele mieszkaniowe w Polsce, Katowice 2005; Polacy biorą miliardy pod hipotekę, www.money.pl

Price of loan, both in Poland and in Great Britain, consists of percentage (WIBOR, LIBOR or EURIBOR rates) and margins of crediting institution. Ways of mortgage loan costs calculation differ in our country. When a debtor takes a loan in zlotys, bank calculates percentage rate basing on WIBOR rate, for Swiss francs it is LIBOR CHF rate. Depending on bank there can be one-month, three-month or six-month rates. In Great Britain calculation of mortgage loan price is based on LIBOR GBP rate.

Graph 4 Dynamics of mortgage loans debt level in Poland in 2002-2007 (year $2002=$ 100)

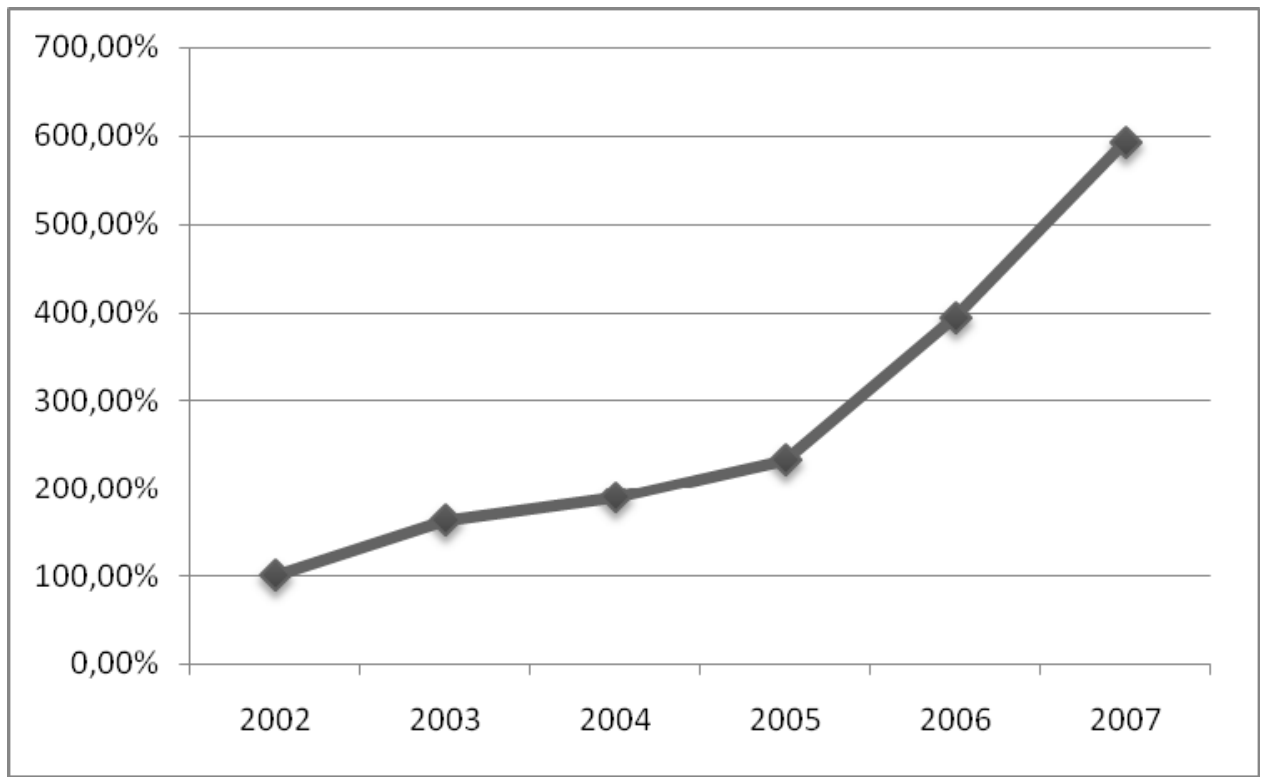

Source: Own researches based on: NBP, A. Szopa, Bariery rozwoju rynku kredytów hipotecznych udzielanych na cele mieszkaniowe w Polsce, Katowice 2005; Polacy biorą miliardy pod hipotekę, www.money.pl 
Graph 5 presents fluctuations of percentage of mortgage loans in Great Britain and in Poland. Mortgage loans in Poland in 2007 were charged lower than on Islands. But the trend is increasing and stable in both countries. You can easily notice fluctuations of percentage rates in Poland. From 2002 percentage rates decreased from $9.62 \%$ to 5.5\% in 2006 and from that time they started to grow - an increase of 1.35 percentage point from the level of $6.9 \%$ took place within twelve months. Higher percentage rates are characteristic for the British market. In the researched period percentage rate increased about 1.75 percentage points. Growth of percentage rates level was not as dynamic as on the Polish market. In 2007 average difference between mortgage loan percentage rate in Poland and in Great Britain amounted to 0.1 percentage points only.

\section{Graph 5 Comparison of mortgage loans percentage rates in Poland and in Great Britain in 2002-2007 (\%)}

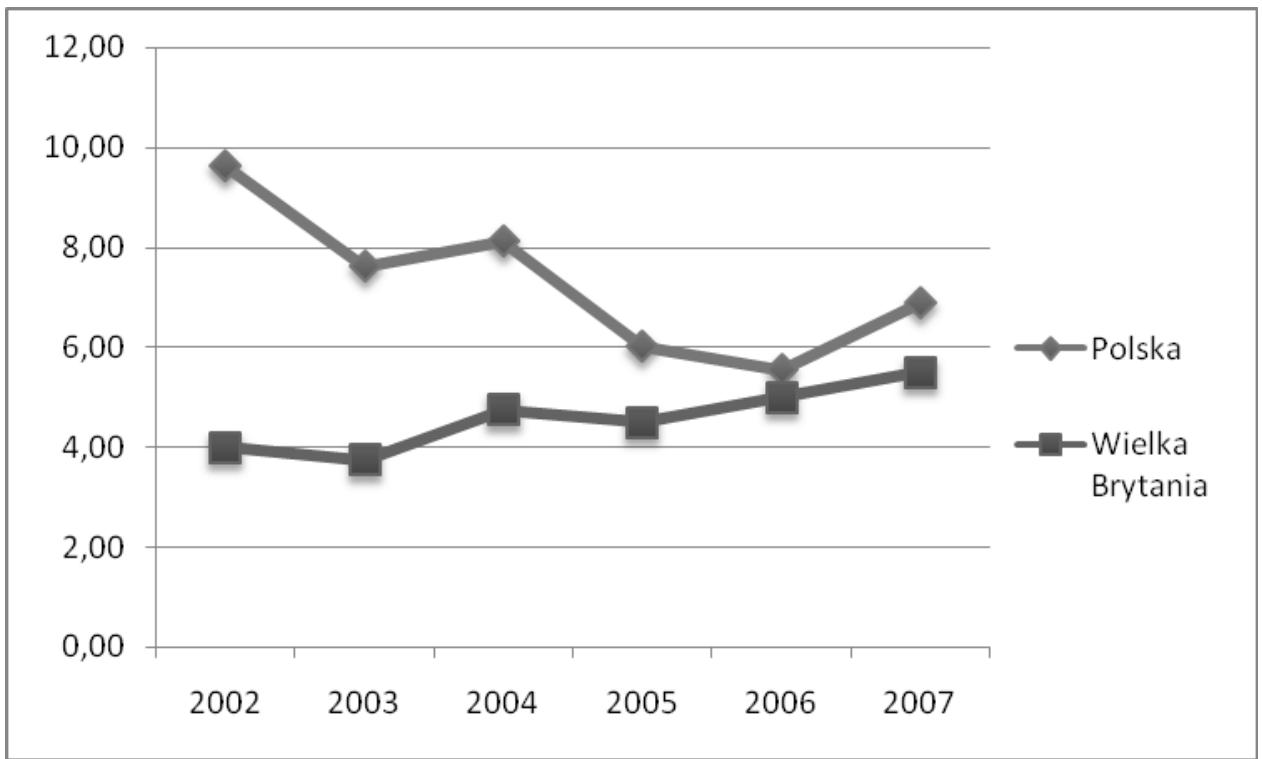

Source: Own research based on Bank of England and National Bank of Poland

Mortgage loans in Swiss francs are very attractive in Poland now because percentage rate and resulted from it instalment level together with interests are lower than for loans in zlotys. Important factor that encourages clients to use this option of debt is a low risk of fluctuation of short-term percentage rate LIBOR CHF, in contrast with frequent fluctuations of WIBOR. Risk that should be taken into consideration by clients is an exchange value risk

It is hard to forecast development of exchange rate of, for example, Swiss franc in the future, but debtors turn their attention more to instalments amount than to exchange value risk. $^{30}$

Tables 3 and 4 compare prices of mortgage loans in Poland and in Great Britain. Differences in percentage in both countries in 2007 are quite small and weigh in favour of the Polish market that offers relatively cheaper mortgage products in zlotys. For example, the cheapest mortgage loan among the biggest Polish lenders (5.91\% in zlotys) can be granted in Bank Millenium. On Islands the most interesting percentage starting from $5.99 \%$, offers Barclays Bank.

\footnotetext{
${ }^{30}$ Mortgage loans will be more expensive in 2008, Gold Finance, www.finanse.egospodarka.pl , 15.12.2008
} 
Table 3. Percentage rates of mortgage loans of the biggest lenders in Great Britain in 2007

\begin{tabular}{|l|c|}
\hline Lender & Percentage rate \\
\hline HBOS & $6,25-7,00 \%$ \\
\hline Abbey & $6,43-7,09 \%$ \\
\hline Lloyds TSB & $5.99-7,90 \%$ \\
\hline Nationwide & $6,49-7,35 \%$ \\
\hline Nothern Rock & $6,49-7,40 \%$ \\
\hline The RBS & $6,54-7,19 \%$ \\
\hline Barclays & $5,99-6,29 \%$ \\
\hline
\end{tabular}

Source: Own research based on www.mortgages.co.uk

It is hard to compare a final cost of mortgage loan because of very high lenders arrangement fees, i.e. commissions and other fees charged both in Poland and abroad. Moreover, share of costs connected with instalment's repayment and interests can be lower within the income of the British borrower because his salaries are much higher than in Poland, except of nominally higher mortgage loan cost in Great Britain.

Table 4. Percentage rates of mortgage loans of the biggest lenders in Poland in 2007

\begin{tabular}{|l|c|c|}
\hline \multirow{2}{*}{ Lender } & \multicolumn{2}{|c|}{ Percentage rate } \\
\cline { 2 - 3 } & PLN & CHF \\
\hline PKO BP & $6,42 \%$ & $4,57 \%$ \\
\hline Millenium & $5,91 \%$ & $4,20 \%$ \\
\hline BRE Bank & $6,13 \%$ & $4,20 \%$ \\
\hline BPH & $6,00 \%$ & $4,10 \%$ \\
\hline BZ WBK & $6,24 \%$ & $4,62 \%$ \\
\hline Fortis Bank & $6,19 \%$ & $4,16 \%$ \\
\hline ING Bank Śląski & $6,19 \%$ & $\mathrm{n} / \mathrm{a}$ \\
\hline
\end{tabular}

Source: Own research based on P. Majtkowski, Mortgage loans ranking, www.gazeta.pl

British market is the one on which main role play many institutions that would like to enlarge number of their clients. They outdo one another to create modern and much more advanced mortgage products. Graph 2 shows that there are various types of percentage that could be declined or increased within the definite time of loan. Up to 2004 clients tended to debt with loans of variable rate, but the US crisis mentioned in chapter 1, caused fluctuations of percentage rates in Great Britain and tended to be granted with credits of fixed loan rate.

The third component of mortgage loan's price makes various commissions and fees. They are present in both researched countries. Lenders arrangement fee can be calculated as fixed amount or percentage depending of loan's value. Lenders arrangement fee in Poland could reach $3 \%$ of loan's value what meant additional few thousand zlotys to be paid. At present lenders arrangement fee amounts from zero to 50 zlotys depending on bank. It is also 
possible to collect a commission for readiness for the immediate transfer of cash to the borrower. Additionally, you have to pay for visits of building inspector at the construction site and for his valuation. Other costs of loan in Poland make also foreign currency translation fee and redemption penalty that could even reach the level of $1 \%$ of loan's value. ${ }^{31}$

Similarly in Great Britain borrowers are obliged to pay lenders arrangement fee especially if they take credits of fixed and lower loan rate. Broker's fee on Islands is added to total loan's value and in Poland is paid by bank. Depending on conditions of credit agreement broker can obtain from 1.25 to $3 \%{ }^{32}$ In the UK the property should be priced or you have to pay all valuation fees or even $1 \%$ redemption penalty. Characteristic loan costs in Great Britain are switching costs when the client decides that another bank has better offer. This process is called remortgaging. Remortgaging is relatively rare in Poland and sometimes there are transactions known as consolidating credits.

While finalizing a transaction that is underwriting a mortgage loan agreement, both sides - lender and borrower - take risk. The main source of risk is asymmetry in access to information. Lender uses various databases, external sources, for example Credit Information Bureau (BIK) in Poland, where information regarding credit history of clients is gained. Both in Poland and in Great Britain every lender would like to be prevented from signing an agreement with a bankrupt. That is why banks use advanced systems of credit risk valuation. Universally applied is scoring system that collects and analyses information about prospective borrower in order to get a value of probability defining credit risk. Bank takes into consideration client's past in context of taking out loans and their repayments as well as socio-demographic data, i.e. region of his living and work, education, age. Some aspects as changes in borrower's environment that influence directly into his lending capacity are essential for such analysis. Banks and other financial institutions that granted loans in both countries examine income level, current expenses and financial obligations. Applicants (prospective borrowers) very often understate their current expenses and conceal their debts. It enlarges bank's risk because such borrower could not repay instalments at due time and bank could have problems with cash-flow.

Risk is also deepened by character of existing legal regulations, changes on property market, job market and changes of interest rates. If interests' rates grow rapidly interests amount to be repaid by borrower increases quickly. Lending capacity falls down. But if shortterm percentage rates decrease, incomes of borrowers having credits with variable loan rate increase and caused growth of demand for properties also among these people who are interested in buying a house or an apartment and who intend to take out mortgage loan. ${ }^{33}$

Theoretically, if prospective borrower takes out credit with fixed loan rate, he has to know instalments value and which part of his income should be allotted for debt's repayment. If inflation level grows quickly it means necessity to renegotiate percentage with client. Otherwise financing institution would receive relatively less money from borrowers. As mentioned before, banks BPH and Deutsche Bank use these procedures.

Polish market is still teaching from western markets. So, similar security system exists in Poland, i.e. properties when speaking of mortgage loans. Thanks to it you can define what part of property value could be safety financed with mortgage loan. Analysis needs to consider current value of a property and a risk of this value's change. To minimise a risk you have to properly value a property before taking out a mortgage on it. LTV index is usually calculated at the level of $75-80 \%$ of a property value, but quick growth of competitiveness caused that banks and other lenders finance even $110 \%$ of property value. It takes place when

\footnotetext{
${ }^{31}$ B.Półtorak, Kredyt hipoteczny...(as mentioned before)

32 Pośrednicy pracują na banki, www.money.pl

33 D. Miles, The UK...,2004, page. 23
} 
a client does not have any own contribution and he has to buy additional insurances, for example involuntary unemployment cover. The most mortgage loan agreements in Great Britain have $80 \%$ LTV index. $^{34}$

\section{Conclusion}

Cooperative financial companies have dominated on the British mortgage market for many years. Later on, in connection with liberalisation of mortgage market and reduction of limits, a share of banks on this market increased. Finally, banks have leading position. The best prosperous cooperative financial company in 2007 was Abbey.

Polish mortgage market increases violently. Especially after World War II and economic transformation it could freely function and develop. Similarly to the British market, Polish mortgage market is dominated by banks. Cooperative financial companies in Poland have rights to grant mortgage loans from 2006, so their market share is not big. This state differs seriously from the British one where cooperatives have managed themselves very good for more than 200 years.

Moreover, percentage share of mortgage loans in GDP is higher between ten and twenty in Great Britain than in Poland. It reflects not only on high level of market's development but also on its extraordinary complexity, presence of many various market players who do not function in Poland so far.

Apart from that the British mortgage market can vaunt high liberalisation level its activity is regulated by various acts: the Building Sodeties Act, the Banking Act, the Financial Services Act and the Mortgage Conduct of Business Sourcebook. In the UK regulations do not hinder a growth of financial institutions' activities but their aim is to support their functioning and to take care of borrowers' interests. In Poland we have many restrictions that make hard mortgage market to develop. The good example is securitization and troubles with its implementation because of low profitability. Similarly, lack of regulations caused troubles as it took place with mortgage banks that tried to solve currency risk management and interests' rate risk that had been passed over in the act. Many other aspects were not cleared in the act, for instance details regarding banking-mortgage valuation.

Mortgage market in Poland cannot be as proud of wide loan offer as Britain can. Mortgage loans in Poland are divided into fixed and variable loan rate credits only. Flexible form of repayment, i.e. declining of instalments for the first years of repayment, makes our mortgage loans more attractive. Percentage of a loan in Poland often depends on negotiations skills of borrower. Financing institution not always forces percentage on a borrower. There are so many credit offers and mortgage loan products on the British market that you can easily say that mortgage loan there is "made-to-measure", i.e. is adjusted to individual needs of a client. There exist various types of mortgage loans that join elements of both fixed and variable loan rate credits. The most popular are classic fixed loans for more than twenty years, variable loans with discounted interest rate and so-called "tracker" that follows the level of base rate of Bank of England. Wide range of mortgage loans is better developed than in Poland. Following dynamic growth of this market we can suppose that banks will offer more varied forms of mortgage loans very soon.

\footnotetext{
${ }^{34}$ K. Jajuga, Z. Krysiak (as mentioned before)
} 


\section{REFERENCE:}

1. Cyburt P., Prawne i ekonomiczne aspekty działalności banków hipotecznych, www.nbportal.pl dated 13.02.2007

2. Decyzja nr DAR-4/2004 dated 07.04.2004, www.uokik.gov.pl/download

3. Diamond D.B., Lea M.J., United Kingdom, Journal of Housing Research, vol. 3 page.1, 1992,

4. Działalność przedsiębiorstw pośrednictwa kredytowego 2007 roku, Informacje bieżące GUS dated 28.05.2008, www.gus.gov.pl

5. Historia kredytów hipotecznych i listu zastawnego, WWW.rhb.com.pl. dated 20.11.2007

6. Kredyty hipoteczne w 2008 roku będą droższe, Gold Finance, WWW.finanse.egospodarka.pl dated 15.12.2008

7. Miles D., The UK Mortgage Market: Taking a Longer - Term View. Final Report and Recommendations, The Miles Review, 2004

8. Nellis J., The changing structure and role of building societies in the UK financial services sector, in: Management in the Service Sector, Kogan Page Cranfield Management Research Serier, 1993

9. Pais A., Securitization and Rate Setting in the UK Mortgage Market, EFA Berlin Discussion Paper 2002

10. Szopa A., Bariery rozwoju rynku kredytów hipotecznych udzielanych na cele mieszkaniowe w Polsce, 2005

11. Praca zbiorowa edited by K. Jajuga i Z. Krysiak, Ryzyko kredytowe wierzytelności hipotecznych: modelowanie i zarządzanie, ZBP, Warszawa 2004

12. Półtorak B., Kredyt hipoteczny Szansa na własne mieszkanie czy pułapka, www.bankier.pl dated 14.05.2008

13. Pośrednicy pracują na banki, www.money.pl dated 24.05.2008

14. Response from the Association of Mortgage Intermediaries (AMI) to the Mortgage Funding Expert Group and Consumer Industry Dialogue Group Final Reports, 2007

15. Rynek kredytów hipotecznych: Banki hipoteczne poniosły fiasko, WWW.bankier.pl dated 15.05.2008

16. Rynek kredytów hipotecznych 2005, egospodarka.pl datek 12.01.2008

17. Nowości w ofercie kredytów hipotecznych GE Money Banku, WWW.bankier.pl, 22.01.2008

18. Samcik M., SKOK-om pęcznieją portfele, www.skok.pl 12.01.2008

19. SKOK-i wskakują na rynek kredytów hipotecznych, www.money.pl datek 21.03.2008

20. Wielgo M., Czy opłaca się wziąć kredyt o stałym oprocentowaniu? egospodarka.gazeta.pl dated 13.05.2008

21. www.bphbh.pl datek 11.04.2008

22. www.deutsche-bank-pbc.pl dated17.05.2008

23. www.hm-treasury.gov.uk dated 12.03.2007

24. www.kredyt-mieszkaniowe.pl dated 16.11.2007

25. www.fsa.gov.uk dated 13.03.2007

The Building Sodeties Act, 1986

${ }^{1}$ The Financial Services Act, 1987

${ }^{1}$ The Banking Act, 1987

${ }^{1}$ BRE Bank Hipoteczny, Historia kredytów..., www.rhb.com.pl

${ }^{1}$ Sytuacja..., www.inwestycje.pl/nieruchomosci 